\title{
Multiple hydride reduction pathways in isoflavonoids
}

\author{
Auli K. Salakka, Tuija H. Jokela and Kristiina Wähälä
}

\section{Full Research Paper}

\section{Address:}

Department of Chemistry, Laboratory of Organic Chemistry, P.O.Box

55, FIN-00014 University of Helsinki, Finland

\section{Email:}

Auli K. Salakka - auli.salakka@kemira.com; Tuija H. Jokela tuija.h.jokela@helsinki.fi; Kristiina Wähälä* -

kristiina.wahala@helsinki.fi

* Corresponding author

\section{Open Access}

Beilstein Journal of Organic Chemistry 2006, 2, No. 16

doi:10.1186/1860-5397-2-16

Received: 25 May 2006

Accepted: 25 August 2006

Published: 25 August 2006

(c) 2006 Salakka et al; licensee Beilstein-Institut.

License and terms: see end of document.

\section{Abstract}

\section{Background}

Isoflavonoids are of interest owing to their appearance in metabolic pathways of isoflavones, and their estrogenic and other physiological properties, making them promising lead compounds for drug design.

\section{Results}

The reduction of isoflavones by various hydride reagents occurs by a 1,4-pathway in contrast to ordinary $\beta$-alkoxy- $\alpha, \beta$-unsaturated ketones. Isoflavan-4-ones, cis- and trans-isoflavan-4-ols, $\alpha$-methyldeoxybenzoins or 1,2-diphenylprop-2-en-1-ols are obtained depending on the hydride reagent, mostly in good yields. The stereoselective reduction of isoflavan-4-ones is also discussed.

\section{Conclusion}

The work described in this paper shows that most structural types of reduced isoflavonoids are now reliably available in satisfactory or good yields by hydride reductions to be used as authentic reference compounds in analytical and biological studies.

\section{Background}

The reduction of isoflavones $\mathbf{1}$ has been actively studied during the last twenty years, owing to the range of interesting biological effects [1-3] - estrogenic activity, promise in cancer, osteoporosis, and coronary heart disease prevention - shown by the isoflavones themselves and their reduced metabolites. There are some reports [4-8] of total syntheses of reduced isoflavonoid structures from commercially available starting materials but overall yields in these multistep procedures tend to be low, and free hydroxy groups are not compatible. Another strategy involves the hydrogenation of isoflavones using a palladium or platinum catalyst but mixtures of reduction products are often formed $[9,10]$. Certain hydride reagents have been tested, as discussed below, for the reduction of simple or protected isoflavones but many of the early results are contradictory or rely on indeterminate product characterization.

The reduction of simple (nonflavonoid) $\beta$-alkoxy- $\alpha, \beta$-unsaturated ketones by hydride reagents $\left(\mathrm{NaBH}_{4}, \mathrm{LiAlH}_{4}, \mathrm{DIBAH}\right)$ 
occurs normally by 1,2-attack, this being a key step in the well known "carbonyl transposition" of 1,3-diketone enol ethers into enones $\left(\mathrm{R}^{3} \mathrm{O}-\mathrm{CR}=\mathrm{CR}^{1}-\mathrm{COR}^{2} \rightarrow \mathrm{R}-\mathrm{CO}-\mathrm{CR}^{1}=\mathrm{CHR}^{2}\right)$. [11-15] Prior to our work there were no reports on the reduction of isoflavones containing free hydroxy groups which nevertheless are common, usually at one or several of the C-5, C-7 and C-4' sites, in the naturally occurring isoflavonoids. It is to be expected that the presence of the phenolic hydroxyls, or the derived phenolate anions, will alter the reactivity pattern of the parent isoflavone system, besides perhaps decreasing the overall reactivity due to solubility reasons. For example, any tendency of hydride attack at the $\mathrm{C}-2$ will be opposed by electron feeding from the 4'-OH group while an $\mathrm{OH}$ group at $\mathrm{C}-5$ or $\mathrm{C}-7$ will discourage attack at $\mathrm{C}-2$ and $\mathrm{C}-4$. Thus there was ample room for the development of reliable methods for the synthesis of hydroxy-substituted isoflavone metabolites, and for clarification of the course of reduction of isoflavones with various hydride reducing agents. We present here experimental details of our own results in this field together with a thorough survey of the literature. The discussion is based on the types of reduced isoflavonoid structures formed (Figure 1), i.e., isoflavanones $\mathbf{2}$, cis-isoflavan-4-ols 3, trans-isoflavan-4-ols 4, the ring opened $\alpha$-methyldeoxybenzoins 5 and 1,2-diaryl-2-propen-1-ols $\mathbf{6}$, and isoflavenes $\mathbf{7}$ and $\mathbf{8}$ (hydride reductions do not lead to isoflavans 9, which however are obtained by catalytic hydrogenation [10,
$16,20])$. Incidentally, it is appropriate to point out that flavones do not undergo similar reductive metabolism in mammals as described above for isoflavones. We will nevertheless present at a later date certain findings on the hydride reduction pathways in flavones.

\section{Results and Discussion Isoflavanones (2)}

Isoflavanones result from the 1,4-reduction of isoflavones. The resonance contributor $\mathbf{1 0}$ will encourage this mode of attack. DIBAH, normally a preferential 1,2-reducer, reacts with methoxy-, benzyloxy-, MOMO- and MEMO-substituted isoflavones to give the isoflavanones in 40-93\% yield [16, 21-23] (Table 1). Our own work has shown that even unprotected hydroxy-substituted isoflavones are reduced by a large excess of DIBAH in $50-70 \%$ yield (Table 1). The simple borohydride reagents reduce isoflavones to the isoflavanols (see below) but the Selectrides ${ }^{\circledR}$ give $60-88 \%$ yields of isoflavanones in the absence of hydroxy substituents according to our results (Table 1). There is no significant difference between the $\mathrm{K}$ - and L-Selectride ${ }^{\circledR}$. In the literature, there is an isolated report of the reduction of a MOM substituted isoflavone by L-Selectride ${ }^{\circledR}$ in $40 \%$ yield (Table 2) [16]. Methoxy substituted isoflavones have also been reduced by sodium hydrogen telluride to give isoflavan-4-ones in $61-71 \%$ yields [24].<smiles>O=c1c(-c2ccccc2)coc2ccccc12</smiles>

1 I soflavone<smiles>O[C@@H]1c2ccccc2OC[C@H]1c1ccccc1</smiles>

4 trans-1 soflavan-4-ol<smiles>C1=C(c2ccccc2)Cc2ccccc2O1</smiles>

72-soflavene<smiles>O=C1c2ccccc2OCC1c1ccccc1</smiles>

2 I soflavan-4-one<smiles>CC(C(=O)c1ccccc1O)c1ccccc1</smiles>

$5 \alpha-$ Methyldeoxybenzoin<smiles>C1=C(c2ccccc2)COc2ccccc21</smiles>

$83 \dashv$ soflavene

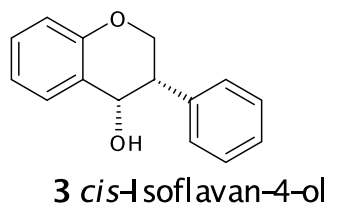<smiles>C=C(c1ccccc1)C(O)c1ccccc1O</smiles>

6 1,2-Diaryl-2-propen-1-ol<smiles>c1ccc(C2COc3ccccc3C2)cc1</smiles>

9 I soflavan<smiles>[O-]c1c(-c2ccccc2)c[o+]c2ccccc12</smiles>

10<smiles>OC1C(c2ccccc2)=COc2ccccc21</smiles>

11 2-I soflaven-4-ol 
Table 1: Reduction of isoflavones to isoflavanones. ${ }^{\text {a }}$<smiles>[R7]c1c([R7])c([R7])c([C@H]2COc3c([R7])c([R7])c([R7])c([P])c3C2=O)c([R7])c1[R7]</smiles>

a all $\mathrm{R}$ groups $=\mathrm{H}$

b $\mathrm{R}^{7}=\mathrm{OMe}$, other $\mathrm{R}$ groups $=\mathrm{H}$

c $\mathrm{R}^{4^{\prime}}=\mathrm{R}^{7}=\mathrm{OMe}$, other $\mathrm{R}$ groups $=\mathrm{H}$

$\mathbf{d ~ R}^{7}=\mathrm{OH}$, other $\mathrm{R}$ groups $=\mathrm{H}$

e $\mathrm{R}^{4^{\prime}}=\mathrm{OMe}, \mathrm{R}^{7}=\mathrm{OH}$, other $\mathrm{R}$ groups $=\mathrm{H}$

$f^{4^{\prime}}=\mathrm{OMe}, \mathrm{R}^{5}=\mathrm{R}^{7}=\mathrm{OH}$, other $\mathrm{R}$ groups $=\mathrm{H}$

\begin{tabular}{|c|c|c|c|c|c|c|c|c|c|c|}
\hline $\mathrm{R}^{2^{\prime}}$ & $\mathrm{R}^{3^{\prime}}$ & $\mathrm{R}^{4^{\prime}}$ & $\mathrm{R}^{5^{\prime}}$ & $\mathrm{R}^{6^{\prime}}$ & $\mathrm{R}^{5}$ & $\mathrm{R}^{6}$ & $\mathrm{R}^{7}$ & $\mathrm{R}^{8}$ & reductant, eqs & yield $\%$ \\
\hline & & & & & & & & & DIB $^{b}, 4$ & 72 \\
\hline & & & & & & & & & $\mathrm{SEL}^{\mathrm{C}}, 4$ & 96 \\
\hline & & & & & & & $\mathrm{OH}$ & & DIB, 10 & 68 \\
\hline & & & & & & & & & SEL, 8 & 0 \\
\hline & & & & & & & $\mathrm{OMe}$ & & DIB, 2.5 & $90^{\mathrm{d}, \mathrm{e}}$ \\
\hline & & & & & & & & & DIB, 6 & 57 \\
\hline & & & & & & & & & SEL, 4 & 84 \\
\hline & & & & & $\mathrm{Me}$ & & OMe & $\mathrm{OMe}$ & DIB, 2.5 & $75^{e}$ \\
\hline & & & & & $\mathrm{OMe}$ & $\mathrm{OMe}$ & OMe & & DIB, 2.5 & $89^{e}$ \\
\hline & & OMe & & & & & $\mathrm{OMe}$ & $\mathrm{OMe}$ & $\mathrm{NaHTe}, 2$ & $68^{f}$ \\
\hline & & $\mathrm{OH}$ & & & & & $\mathrm{OH}$ & & DIB, 25 & 70 \\
\hline & & & & & & & & & SEL, 8 & 0 \\
\hline & & OMe & & & & & $\mathrm{OH}$ & & DIB, 25 & 60 \\
\hline & & OMe & & & & & $\mathrm{OMe}$ & & DIB, 2.5 & $87^{e}$ \\
\hline & & & & & & & & & DIB, 7 & 54 \\
\hline & & & & & & & & & $\mathrm{NaHTe}, 2$ & $61^{f}$ \\
\hline & & & & & & & & & SEL, 4 & 82 \\
\hline & & OMOM & & & & & OMOM & & DIB, 4.7 & $93^{9}$ \\
\hline & & $\mathrm{OH}$ & & & $\mathrm{OH}$ & & $\mathrm{OH}$ & & DIB, 25 & 50 \\
\hline & & & & & & & & & SEL, 9 & 0 \\
\hline & & OMe & & & $\mathrm{OH}$ & & $\mathrm{OH}$ & & DIB, 25 & 57 \\
\hline & $\mathrm{OMe}$ & $\mathrm{OMe}$ & & & & $\mathrm{OMe}$ & $\mathrm{OMe}$ & & $\mathrm{NaHTe}, 2$ & $71^{f}$ \\
\hline \multirow[t]{2}{*}{ омом } & & OMOM & & & & & OMOM & & DIB, 4.7 & $87^{\mathrm{g}, \mathrm{h}}$ \\
\hline & & & & & & & & & SEL, 2 & $40^{g}$ \\
\hline $\mathrm{OMe}$ & $\mathrm{OMe}$ & $\mathrm{OBn}$ & & & & & $\mathrm{OBn}$ & & DIB, 2.5 & $40^{i}$ \\
\hline OBn & $\mathrm{OMe}$ & $\mathrm{OMe}$ & & & & & $\mathrm{OMe}$ & & DIB, 2.5 & $56^{e}$ \\
\hline OBn & $\mathrm{OBn}$ & $\mathrm{OMe}$ & $\mathrm{OMe}$ & & & & $\mathrm{OMe}$ & & DIB, 1.9 & $52^{\mathrm{j}}$ \\
\hline OBn & OBn & $\mathrm{OBn}$ & & OMe & & & OMe & & DIB, 1.9 & $57^{\mathrm{j}}$ \\
\hline $\mathrm{OBn}$ & $\mathrm{OBn}$ & OMe & $\mathrm{OMe}$ & & & & $\mathrm{OMe}$ & OBn & DIB, 1.9 & $67^{\mathrm{j}}$ \\
\hline $\mathrm{OBn}$ & $\mathrm{OMe}$ & OMe & & & & & OMe & $\mathrm{OBn}$ & DIB, 1.9 & $61^{j}$ \\
\hline OBn & OBn & OBn & & OMe & & & OMe & OBn & DIB, 1.9 & $58^{\mathrm{j}}$ \\
\hline
\end{tabular}

${ }^{a}$ Only substituents other than $\mathrm{H}$ are shown in the Table. Items without a reference are results reported here for the first time. ${ }^{b} \mathrm{DIB}=$ di-isobutylaluminiumhydride. ${ }^{c}$ SEL $=\mathrm{K}$ - or L-Selectride ${ }^{\circledR} .{ }^{d} 2$-Methyl-7-methoxyisoflavone reacted similarly in $63 \%$ yield.[21] ${ }^{e}$ Ref. 21. ${ }^{f}$ Ref. 24. ${ }^{g}$ Ref. 16. ${ }^{h}$ The corresponding tris(methoxyethoxymethoxy)flavone reacted similarly. ${ }^{i}$ Ref. $23 .{ }^{j}$ Ref. 22. 
Table 2: Reduction of isoflavones to isoflavan-4-ols ${ }^{a}$<smiles>[Z6]c1ccc(-c2c([R])oc3c([Y9])c([R])c([R])cc3c2=O)c([R1])c1</smiles>

1<smiles>[Y8]c1ccc([C@H]2C([R])Oc3c(cc([R9])c([R])c3[Y9])[C@@H]2O)c([R4])c1</smiles>

3<smiles>[Y8]c1ccc([C@H]2C([R])Oc3c(cc([R4])c([R])c3[R3])[C@@H]2O)c([R1])c1</smiles>

4

\begin{tabular}{|c|c|c|c|c|c|c|c|c|c|c|}
\hline SM & $\mathrm{R}^{2}$ & $\mathrm{R}^{2^{\prime}}$ & $\mathrm{R}^{4^{\prime}}$ & $\mathrm{R}^{6}$ & $\mathrm{R}^{7}$ & $\mathrm{R}^{8}$ & reductant, eqs, solvent & yield $3+4 \%$ & $3: 4$ ratio & Yld $6 \%$ \\
\hline \multirow[t]{12}{*}{$1 \mathrm{a}$} & & & & & & & $\mathrm{NaBH}_{4}, 2.5, \mathrm{EtOH}$ & 86 & $70: 30$ & 12 \\
\hline & & & & & & & $\mathrm{LiBH}_{4}, 2.5, \mathrm{THF}$ & 56 & $80: 20$ & 40 \\
\hline & & & & & & & $\mathrm{NaBH}_{4}, 2.5, \mathrm{MeOH}$ & $57^{b}$ & 3 only & \\
\hline & & & & & & & $\mathrm{NaBH}_{4}, 2, \mathrm{EtOH}$ & $75^{\mathrm{c}, \mathrm{d}}$ & & \\
\hline & & & & & & & $\mathrm{NaBH}_{4}, 2$, diglyme & $88^{\mathrm{d}, \mathrm{e}}$ & & \\
\hline & & & & & & & $\mathrm{NaBH}_{4}, 3.5, \mathrm{PdCl}_{2}$, aq. THF & 85 & $82: 18$ & \\
\hline & & & & & & & $\mathrm{NaBH}_{4}, \mathrm{H}_{3} \mathrm{BO}_{3}, 2.5, \mathrm{EtOH}$ & 98 & $71: 29$ & \\
\hline & & & & & & & $\mathrm{NaBH}_{4}, \mathrm{CeCl}_{3}, 1.0, \mathrm{DMSO}$ & 99 & 3 only & \\
\hline & & & & & & & $\mathrm{NaBH}_{4}, \mathrm{AlCl}_{3}$, excess., digl. & $81^{d}$ & & \\
\hline & & & & & & & $\mathrm{Zn}\left(\mathrm{BH}_{4}\right)_{2}, 4, \mathrm{Et}_{2} \mathrm{O}$ & 69 & $62: 38$ & 19 \\
\hline & & & & & & & $\mathrm{LiEt}_{3} \mathrm{BH}, 4, \mathrm{THF}$ & 50 & $70: 30$ & \\
\hline & & & & & & & $\mathrm{B}_{2} \mathrm{H}_{6}$, excess, THF & $76^{\mathrm{c}, \mathrm{d}}$ & & \\
\hline \multirow[t]{6}{*}{$1 b$} & & & & & OMe & & $\mathrm{NaBH}_{4}, 2.5, \mathrm{EtOH}$ & 90 & $70: 30$ & 9 \\
\hline & & & & & & & $\mathrm{NaBH}_{4}, \mathrm{H}_{3} \mathrm{BO}_{3}, 3.1, \mathrm{EtOH}$ & $80^{f}$ & 3 only & \\
\hline & & & & & & & $\mathrm{NaBH}_{4}, \mathrm{H}_{3} \mathrm{BO}_{3}, 2.5, \mathrm{EtOH}$ & 97 & $70: 30$ & \\
\hline & & & & & & & $\mathrm{NaBH}_{4}, \mathrm{CeCl}_{3}, 1.5, \mathrm{DMSO}$ & 88 & 3 only & 12 \\
\hline & & & & & & & $\mathrm{LiBH}_{4}, 10, \mathrm{THF}$ & 54 & $70: 30$ & 37 \\
\hline & & & & & & & $\mathrm{LiEt}_{3} \mathrm{BH}, 4, \mathrm{THF}$ & 55 & $65: 35$ & \\
\hline \multirow[t]{7}{*}{$1 c$} & & & OMe & & OMe & & $\mathrm{NaBH}_{4}, 2.5, \mathrm{MeOH}$ & $37^{b}$ & 3 only & \\
\hline & & & & & & & $\mathrm{NaBH}_{4}, 2.5, \mathrm{EtOH}$ & 88 & $70: 30$ & 10 \\
\hline & & & & & & & $\mathrm{NaBH}_{4}, \mathrm{CeCl}_{3}, 2.5, \mathrm{DMSO}$ & 86 & 3 only & 10 \\
\hline & & & & & & & $\mathrm{NaBH}_{4}, \mathrm{H}_{3} \mathrm{BO}_{3}, 2.5, \mathrm{EtOH}$ & 96 & $70: 30$ & \\
\hline & & & & & & & $\mathrm{LiBH}_{4}, 10, \mathrm{THF}$ & 70 & $77: 23$ & 10 \\
\hline & & & & & & & $\mathrm{Zn}\left(\mathrm{BH}_{4}\right)_{2}, 2, \mathrm{Et}_{2} \mathrm{O}$ & 74 & $62: 38$ & \\
\hline & & & & & & & $\mathrm{LiEt}_{3} \mathrm{BH}, 4, \mathrm{THF}$ & 36 & $78: 22$ & \\
\hline 1 & & OMOM & OMOM & & OMOM & & $\begin{array}{l}\mathrm{NaBH}_{4}, 15.9, \mathrm{EtOH}, \mathrm{THF} \\
\mathrm{LiBH}_{4}, 10, \mathrm{THF}\end{array}$ & $\begin{array}{l}87^{\mathrm{g}} \\
82^{\mathrm{g}}\end{array}$ & $\begin{array}{l}65: 35 \\
57: 43\end{array}$ & \\
\hline 1 & $\mathrm{Me}$ & & & $\mathrm{Br}$ & OMe & & $\mathrm{NaBH}_{4}, 4.2, \mathrm{EtOH}$ & $25^{\mathrm{e}, \mathrm{h}}$ & & \\
\hline 1 & $\mathrm{Me}$ & & & $\mathrm{Br}$ & OBn & & $\mathrm{NaBH}_{4}, 4.2, \mathrm{EtOH}$ & $22^{e, h}$ & & \\
\hline 1 & $\mathrm{Me}$ & & & & OMe & $\mathrm{Br}$ & $\mathrm{NaBH}_{4}, 4.2, \mathrm{EtOH}$ & $20^{e, h}$ & & \\
\hline 1 & $\mathrm{Me}$ & & & $\mathrm{Br}$ & OMe & $\mathrm{Br}$ & $\mathrm{NaBH}_{4}, 4.2, \mathrm{EtOH}$ & $20^{e, h}$ & & \\
\hline
\end{tabular}

a Only substituents other than $\mathrm{H}$ are shown. According to our results, $\mathrm{OH}$ substituted isoflavones are not reduced, nor are such reactions reported in the literature. Items without a reference are results reported here for the first time. ${ }^{b}$ Ref. $25 .{ }^{c}$ Product was given as 2 -isoflaven-4-ol. ${ }^{d}$ Ref. $28 .{ }^{e}$ Product ratio not given. ${ }^{f}$ Ref. 26. ${ }^{g}$ Ref. 16. ${ }^{h}$ Ref. 27.

\section{Isoflavanols $(3,4)$}

Full reduction at the heterocyclic ring of isoflavones by $\mathrm{LiBH}_{4}$ or $\mathrm{NaBH}_{4}$ leads to isoflavanols in $20-91 \%$ yield (Table 2), [16, 25-28] except with hydroxy substituted substrates which do not react at all. Apparently the first step involves a 1,4-addition to give the isoflavanone enolate which picks up a proton from the solvent and is reduced further to the saturated alcohol. There are no reports of the intermediacy of the alternative 1,2-reduction products, the allylic alcohols 11 which in fact appear very incompletely known in the chemical literature (see below). Similarly, the reduction of isoflavanones 2 by $\mathrm{LiBH}_{4}, \mathrm{NaBH}_{4}$, L-Selectride ${ }^{\circledR}$ or $\mathrm{Li}(t-\mathrm{BuO})_{3} \mathrm{AlH}$ gives mixtures of $c i s-\mathbf{3}$ and 
Table 3: Reduction of isoflavanones to isoflavan-4-ols ${ }^{a}$<smiles>[R][Z19]CC</smiles>

2<smiles>[R]c1ccc2c(c1)OC[C@H](c1ccc([R4])c([R1])c1[R2])[C@H]2O</smiles>

3<smiles></smiles>

4

\begin{tabular}{|c|c|c|c|c|c|c|c|}
\hline SM & $\mathrm{R}^{2^{\prime}}$ & $\mathrm{R}^{3^{\prime}}$ & $\mathrm{R}^{4^{\prime}}$ & $\mathrm{R}^{7}$ & reductant, eqs, solvent & yield $3+4 \%$ & $3: 4$ ratio \\
\hline $2 a$ & & & & & $\begin{array}{l}\mathrm{NaBH}_{4}, \text { ng., EtOH } \\
\mathrm{NaBH}_{4}, 2, \mathrm{MeOH}, \mathrm{THF} \\
\mathrm{Li}(\mathrm{t}-\mathrm{BuO})_{3} \mathrm{AlH}, 10, \mathrm{THF} \\
\mathrm{B}_{2} \mathrm{H}_{6}, 80, \mathrm{THF}\end{array}$ & $\begin{array}{l}99^{b} \\
99^{c} \\
99^{c} \\
98^{c}\end{array}$ & $\begin{array}{l}70: 30 \\
42: 58 \\
34: 66 \\
3 \text { only }\end{array}$ \\
\hline $2 b$ & & & & OMe & $\begin{array}{l}\mathrm{NaBH}_{4}, 2, \mathrm{MeOH}, \mathrm{THF} \\
\mathrm{NaBH}_{4}, 1.2, \mathrm{EtOH} \\
\mathrm{Li}(\mathrm{t}-\mathrm{BuO})_{3} \mathrm{AlH}, 10, \mathrm{THF} \\
\mathrm{L}-\mathrm{Selectride}_{\mathrm{i}} \mathrm{ng} \\
\mathrm{B}_{2} \mathrm{H}_{6}, 80, \mathrm{THF} \\
\mathrm{BTED}, 0.7, \mathrm{THF}\end{array}$ & $\begin{array}{l}99^{c} \\
67^{d} \\
99^{c} \\
99^{c} \\
99^{c} \\
98^{c}\end{array}$ & $\begin{array}{l}44: 56 \\
67: 33 \\
33: 67 \\
37: 63 \\
3 \text { only } \\
3 \text { only }\end{array}$ \\
\hline 2 & & & $\mathrm{OH}$ & $\mathrm{OH}$ & $\mathrm{LiBH}_{4}, 6.9, \mathrm{THF}$ & $94^{\mathrm{e}}$ & $70: 30$ \\
\hline 2 & & & OTBDMS & OTBDMS & $\mathrm{LiBH}_{4}, 2, \mathrm{THF}$ & $96^{f}$ & $70: 30$ \\
\hline \multirow[t]{2}{*}{ 2c } & & & OMe & OMe & $\begin{array}{l}\mathrm{NaBH}_{4}, 2, \mathrm{THF}, \mathrm{MeOH} \\
\mathrm{NaBH}_{4}, 1.2, \mathrm{EtOH} \\
\mathrm{Li}(\mathrm{t}-\mathrm{BuO})_{3} \mathrm{AlH}, 10, \mathrm{THF} \\
\mathrm{B}_{2} \mathrm{H}_{6}, 80, \mathrm{THF}\end{array}$ & $\begin{array}{l}99^{c} \\
50^{d} \\
99^{c} \\
97^{c}\end{array}$ & $\begin{array}{l}43: 57 \\
3 \text { only } \\
34: 66 \\
3 \text { only }\end{array}$ \\
\hline & & & & & BTED ${ }^{9}, 0.7$, THF & $97^{c}$ & 3 only \\
\hline \multirow[t]{4}{*}{2} & & OMe & OMe & OMe & $\mathrm{NaBH}_{4}, 2, \mathrm{THF}, \mathrm{MeOH}$ & $99^{c}$ & $36: 64$ \\
\hline & & & & & $\mathrm{Li}(\mathrm{t}-\mathrm{BuO})_{3} \mathrm{AlH}, 10, \mathrm{THF}$ & $99^{c}$ & $32: 68$ \\
\hline & & & & & $\mathrm{B}_{2} \mathrm{H}_{6}, 80, \mathrm{THF}$ & $98^{\mathrm{c}}$ & 3 only \\
\hline & & & & & BTEDg,0.7,THF & $98^{\mathrm{C}}$ & 3 only \\
\hline \multirow[t]{3}{*}{2} & OMOM & & OMOM & OMOM & $\mathrm{LiBH}_{4}, 10, \mathrm{THF}$ & $73^{h}$ & $55: 45$ \\
\hline & & & & & $\mathrm{LiAlH}_{4}, 17, \mathrm{THF}$ & $78^{\mathrm{h}}$ & $45: 55$ \\
\hline & & & & & $\mathrm{NaBH}_{4}, 15.9, \mathrm{THF}, \mathrm{MeOH}$ & $91^{\mathrm{h}}$ & $70: 30$ \\
\hline
\end{tabular}

${ }^{a}$ Only substituents other than $\mathrm{H}$ are shown. ng not given ${ }^{b}$ Ref. $31 .{ }^{c}$ Ref. $29 .{ }^{d}$ Ref. $30 .{ }^{e}$ Ref. $32 .{ }^{f}$ Ref. $33 .{ }^{g}$ bis-t-butylthioethane diborane. ${ }^{h}$ Ref. 16.

trans-isoflavan-4-ols 4 (Table 3). [16,29,34] Isoflavanones are reduced by electrophilic hydrides (borane-tetrahydrofuran, bistert-butylthioethane borane) diastereoselectively to cisisoflavan-4-ols, but a large excess of the reducing agent is usually needed [29].

Although it was realized by the early workers that diastereomeric mixtures of isoflavanols would presumably be formed, there were no reliable methods to determine their structures. In some papers, the products are summarily assigned the cis [25, 26] or trans [35-38] structures. However, rigorous NMR analysis has recently made it possible to establish cis- and trans-structures for the isoflavanol products and to study their conformational equilibria $[32,34]$. Borohydride reductions generally give a small preference for the cis products as suggested by Cram's rule [39]. We are not aware of any examples in the literature of single enantiomers of isoflavanone or isoflavanol metabolites, nor have such compounds been reported as hydride reduction products of isoflavones. In view of the significant biological properties of the reduced metabolites it will be interesting to examine the behaviour of the pure enantiomers.

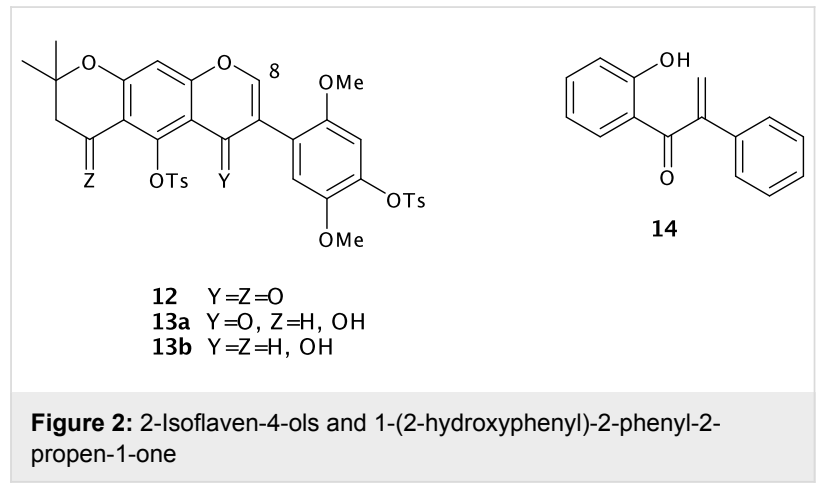


Table 4: Reduction of isoflavones to $\alpha$-methyldeoxybenzoins and 1,2-diaryl-2-propen-1-ols ${ }^{a}$<smiles>[R]c1ccc(-c2coc3cc([R])cc([R])c3c2=O)c([R])c1</smiles>

1<smiles>[R][X]c1ccc(C(C)C(=O)c2c([R6])cc([3H])cc2O)c([R2])c1</smiles>

5<smiles>[Z6]c1ccc(C(=C)C(O)c2c([R])cc([Z6])cc2O)c([R1])c1</smiles>

6

a all $\mathrm{R}$ groups $=\mathrm{H}$

b $\mathrm{R}^{7}=\mathrm{Me}$, other $\mathrm{R}$ groups $=\mathrm{H}$

c $\mathrm{R}^{4}=\mathrm{R}^{7}=\mathrm{Me}$, other $\mathrm{R}$ groups $=\mathrm{H}$

\begin{tabular}{|c|c|c|c|c|c|c|}
\hline \multirow[t]{2}{*}{$\mathrm{R}^{2^{\prime}}$} & \multirow[t]{2}{*}{$\mathrm{R}^{4^{\prime}}$} & \multirow[t]{2}{*}{$\mathrm{R}^{5}$} & \multirow[t]{2}{*}{$\mathrm{R}^{7}$} & \multirow[t]{2}{*}{ reductant, eqs, solvent } & \multicolumn{2}{|c|}{ yield (\%) } \\
\hline & & & & & of 5 & of 6 \\
\hline & & & & $\mathrm{LiAlH}_{4}, 2.5, \mathrm{THF}$ & $27^{\mathrm{b}}$ & 48 \\
\hline & & & & $\mathrm{Li}(\mathrm{t}-\mathrm{BuO})_{3} \mathrm{AlH}, 5, \mathrm{THF}$ & 74 & 6 \\
\hline & & & & Red-Al, 2.5,THF & 12 & 50 \\
\hline & & & & $\mathrm{LiBH}_{4}, 10, \mathrm{THF}$ & 9 & 68 \\
\hline & & & OMe & $\mathrm{LiAlH}_{4}, 2.5, \mathrm{THF}$ & $29^{b}$ & 50 \\
\hline & & & & $\mathrm{LiAlH}_{4}, 1, \mathrm{THF}$ & $62^{c}$ & - \\
\hline & & & & $\mathrm{Li}(\mathrm{t}-\mathrm{BuO})_{3} \mathrm{AlH}, 10, \mathrm{THF}$ & 88 & 12 \\
\hline & & & & $\mathrm{LiBH}_{4}, 10, \mathrm{THF}$ & 7 & 37 \\
\hline & OMe & & OMe & $\mathrm{LiAlH}_{4}, 3.3, \mathrm{THF}$ & $27^{b}$ & 70 \\
\hline & & & & $\mathrm{Li}(\mathrm{t}-\mathrm{BuO})_{3} \mathrm{AlH}, 10, \mathrm{THF}$ & 88 & 12 \\
\hline & & & & $\mathrm{LiBH}_{4}, 10$, THF & 5 & 10 \\
\hline & & & $\mathrm{OH}$ & $\mathrm{LiAlH}_{4}, 3.3, \mathrm{THF}$ & $60^{\mathrm{b}}$ & - \\
\hline & & & & $\mathrm{Li}(\mathrm{t}-\mathrm{BuO})_{3} \mathrm{AlH}, 8, \mathrm{THF}$ & - & - \\
\hline & $\mathrm{OH}$ & & $\mathrm{OH}$ & $\mathrm{LiAlH}_{4}, 5.5, \mathrm{THF}$ & $42^{b}$ & - \\
\hline & & & & $\mathrm{Li}(\mathrm{t}-\mathrm{BuO})_{3} \mathrm{AlH}, 10, \mathrm{THF}$ & - & - \\
\hline & OMe & & $\mathrm{OH}$ & $\mathrm{LiAlH}_{4}, 3.3, \mathrm{THF}$ & $42^{b}$ & - \\
\hline & $\mathrm{OH}$ & $\mathrm{OH}$ & $\mathrm{OH}$ & $\mathrm{LiAlH}_{4}, 5.5, \mathrm{THF}$ & $66^{b}$ & - \\
\hline & OMe & $\mathrm{OH}$ & $\mathrm{OH}$ & $\mathrm{LiAlH}_{4}, 4.3, \mathrm{THF}$ & $70^{\mathrm{b}}$ & - \\
\hline & $\mathrm{OH}$ & & OMe & $\mathrm{LiAlH}_{4}, 3.3, \mathrm{THF}$ & $17^{\mathrm{b}}$ & 34 \\
\hline OMOM & OMOM & & OMOM & $\mathrm{LiAlH}_{4}, 7.9, \mathrm{THF}$ & $6^{d}$ & - \\
\hline
\end{tabular}

${ }^{a}$ Only substituents other than $\mathrm{H}$ are shown in the Table. Items without a reference are results reported here for the first time. ${ }^{b}$ Ref. $43 .{ }^{c}$ Ref. $44 .{ }^{d}$ Ref. 16.

\section{2-Isoflaven-4-ols (11)}

There are very few reports of this class of compounds, either from reductive processes or otherwise. In 1965, the reduction of the parent isoflavone by $\mathrm{NaBH}_{4}$ in EtOH or diborane in THF was claimed [28] to furnish 2-isoflaven-4-ol in 75-76\% yield, but unfortunately the characterization of this product relied on elemental analysis only. More recently, Japanese workers [40] reported that the reduction of $\mathbf{1 2}$ (Figure 2) by $\mathrm{NaBH}_{4}$ in the presence of $\mathrm{PdCl}_{2}$ in $\mathrm{THF}-\mathrm{H}_{2} \mathrm{O}$ gave a 1:1 mixture of the ketone 13a and the diol 13b (Figure 2). A ${ }^{1} \mathrm{H}$ NMR spectrum was given for the latter isoflavenol but there appear to be certain discrepancies, notably in the $\delta$ value (8.69) reported for the H- 8 which is some $2 \delta$ units in excess of what would be expected for such a vinyl ether proton. Thus more work is required to fully confirm the nature of this class of reduction products. In the event, in our studies the reduction of isoflavone $1 \mathbf{a}$ by $\mathrm{NaBH}_{4}$ in the presence of $\mathrm{PdCl}_{2}$ in THF- $\mathrm{H}_{2} \mathrm{O}$ gave a 82:18 mixture of cisand trans-isoflavan-4-ol 3a, 4a while no 2-isoflaven-4-ols were observed. The absence of such 1,2-reduction products, or structures conceivably derivable thereof such as 2- or 3-isoflavenes $(7,8)$, even in the $\mathrm{CeCl}_{3}$-complexed $\mathrm{NaBH}_{4}$ reductions, must reflect the good stabilization obtainable via resonance heteroring stabilization (10) in the isoflavones. As already mentioned, this is in contrast to the behaviour of simple nonflavonoid $\beta$-alkoxy- $\alpha, \beta$-unsaturated ketones which prefer 1,2attack by hydride. 


\section{Isoflavenes $(7,8)$ and isoflavans (9)}

In the early work, [41] there is a mention of 7,4'-dimethoxy-2methyl-3-isoflavene being obtained in $15 \%$ yield from the reduction of the corresponding isoflavone by $\mathrm{LiAlH}_{4}$ in $\mathrm{Et}_{2} \mathrm{O}$ benzene but there is no structural data on the product other than elemental analysis, itself quite accurate. Similarly 2',4'dimethoxy-3',6,7-trihydroxyisoflav-3-ene was reported from the reduction of 2',4'-dimethoxy-3',6,7-trihydroxyisoflavan-4-one with $\mathrm{LiAlH}_{4}$ in low yield [42]. More recent work by us [43] and others $[16,44]$ would indicate that the normal course of $\mathrm{LiAlH}_{4}$ reduction of isoflavones leads to deoxybenzoins and propenols (see below and Table 4).

Published syntheses of 2- and 3-isoflavenes involve the reduction of 3-arylcoumarins, [45-47] the corresponding aldehyde hemiacetals, [7] isoflavylium salts [48-50] or of isoflavones by the Clemmensen reaction [51]. Low-yielding non-reductive routes to 2 - and/or 3-isoflavenes have also been reported [52, 53]. 2-Isoflavenes 7 however remain mostly poorly character- ized, and some of the NMR spectral details reported [7,51,52] appear inconsistent with the 2-isoflavenoid structure. As far as the NMR spectra of 2-isoflavenes are concerned, a recent study clears this issue by 2D NMR work on a natural 2-isoflavene, [54] establishing that the $\mathrm{H}-2$ and $\mathrm{H}-4$ protons appear at $\delta 6.87$ and 3.61, respectively, much as expected by correlation data shift calculations. Isoflavans (9) have not been prepared by hydride reductions, but by catalytic hydrogenation of isoflavones [10,16-20].

\section{Deoxybenzoins (5) and propenols (6)}

Isoflavanones undergo a facile retro-Michael-type ring opening $[21,55]$ under basic conditions to give the propenone intermediate 14 (Figure 2), sometimes considered [56] to be an independent isoflavone metabolite but presumably just an artefact in reality. As regards the synthesis of isoflavanones by DIBAH reduction of isoflavones (see above), we found that unless the workup is done with cold methanolic $\mathrm{HCl}$, some amount of the propenone 14 will be formed and reduced further to the deoxy-<smiles>[R]c1ccc(-c2coc3cc([R2])c([R6])c([R9])c3c2=O)cc1[R1]</smiles>

1 e, f, $g, h$, i<smiles>[R]c1ccc(C2COc3cc([R4])cc([R])c3C2=O)cc1</smiles>

$2 \mathrm{~g}, \mathrm{~h}$<smiles>[R1]c1ccc(C(C)C(=O)c2c(O)cc([R])c([R])c2[R])cc1[R9]</smiles>

$5 \mathrm{~g}, \mathrm{~h}, \mathrm{j}, \mathrm{k}, \mathrm{I}$<smiles>CCc1ccc(O)cc1</smiles>

15<smiles>Oc1ccc([C@@H]2COc3cc(O)ccc3[C@@H]2O)cc1</smiles>

$3 \mathbf{g}$<smiles>Oc1ccc(C2=COc3cc(O)ccc3C2)cc1</smiles>

$7 \mathbf{g}$<smiles>C=C(C(=O)c1ccc(O)cc1)c1ccccc1</smiles>

16<smiles>Oc1ccc([C@@H]2COc3cc(O)ccc3[C@H]2O)cc1</smiles>

$4 \mathrm{~g}$<smiles>[R]c1ccc2c(c1)OCC(c1ccc([Z10])c([Y])c1)C2</smiles>

9 e, g, k<smiles>OC1=C(c2ccc(O)cc2)COc2cc(O)ccc21</smiles>

17

Figure 3: Dietary isoflavones and their metabolites in humans.

e $\mathrm{R}^{\prime}=\mathrm{OMe}, \mathrm{R} 7=\mathrm{OH}$, other $\mathrm{R}$ groups $=\mathrm{H}$

$\mathrm{f} \mathrm{R}^{4}=\mathrm{OMe}, \mathrm{R} 5=\mathrm{R} 7=\mathrm{OH}$, other $\mathrm{R}$ groups $=\mathrm{H}$

g $\mathrm{R}^{4^{\prime}}=\mathrm{R} 5=\mathrm{R} 7=\mathrm{OH}$, other $\mathrm{R}$ groups $=\mathrm{H}$

h R ${ }^{4}=\mathrm{R} 7=\mathrm{OH}$, other $\mathrm{R}$ groups $=\mathrm{H}$

i $\mathrm{R}^{4}=\mathrm{R} 7=\mathrm{OH}, \mathrm{R} 6=\mathrm{OCH} 3$, other $\mathrm{R}$ groups $=\mathrm{H}$

j $R^{4}=R 6=R 7=O H$, other $R$ groups $=H$

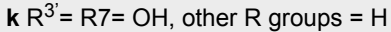

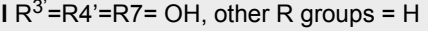


benzoin $\mathbf{5}$. If on the other hand the deoxybenzoins are the actual synthetic targets, the reducing agent of choice is $\mathrm{LiAlH}_{4}$ in THF. This works very well for isoflavones bearing a hydroxy group at $\mathrm{C}-7$ such as genistein, but in isoflavones lacking a $7-\mathrm{OH}$ group another reaction pathway competes leading to the propenols 6 [43] as byproducts (see below). We have discussed a possible mechanism to explain these hydroxyl-dependent divergent pathways [43].

To summarize, all hydride addition reactions with isoflavones appear to involve an initial 1,4-addition to give the isoflavanone enolate. In a hydroxylic solvent, or even on workup under basic conditions, the ketone is generated, and reduced further to the saturated alcohol $\left(\mathrm{NaBH}_{4}\right)$. In a nonprotic solvent, the $\beta$-aryloxyenolate will undergo a retro-Michael addition, giving the phenolate anion of the ring opened 2-propen-1-one which may undergo a 1,2- or 1,4-addition of hydride $\left(\mathrm{LiAlH}_{4}, \mathrm{LiBH}_{4}\right)$. If the $O$-metal bond in the initial enolate is very tight, the ring opening does not occur and allows the isolation of the isoflavanone (DIBAH, Selectrides ${ }^{\circledR}$ ). The presence and number of hydroxy or alkoxy substituents in the substrates does not have a major effect in these reductions except in the case of $\mathrm{NaBH}_{4}$ reduction which fails completely presumably due to solubility reasons, and the $\mathrm{LiAlH}_{4}$ reduction where the outcome depends on the presence or absence of an $\mathrm{OH}$ group at C-7. Based on our and previous results by other workers, the reducing agents of choice for the synthesis of reduced isoflavonoids are as follows:

isoflavanones (2) from non-hydroxylated isoflavones DIBAH or Selectrides ${ }^{\circledR}$

isoflavanones (2) from hydroxylated isoflavones DIBAH

cis-isoflavanols (3) from non-hydroxylated isoflavones $\mathrm{NaBH}_{4} /$ $\mathrm{CeCl}_{3}$

cis-isoflavanols (3) from hydroxylated isoflavones no good methods

cis-isoflavanols (3) from non-hydroxylated isoflavanones $\mathrm{B}_{2} \mathrm{H}_{6}$ or BTED

trans-isoflavanols (4) from isoflavones no good methods

trans-isoflavanols (4) from isoflavanones $\mathrm{Li}(t-\mathrm{BuO})_{3} \mathrm{AlH}$

2-isoflaven-4-ols (11) from isoflavones uncertain

isoflavenes $(\mathbf{7}, \mathbf{8})$ from isoflavones Clemmensen isoflavans (9) from isoflavones $\mathrm{H}_{2}, \mathrm{Pd} / \mathrm{BaSO}_{4}$

$\alpha$-methyldeoxybenzoins (5) from non-hydroxylated isoflavones $\mathrm{Li}(t-\mathrm{BuO})_{3} \mathrm{AlH}$

$\alpha$-methyldeoxybenzoins (5) from hydroxylated isoflavones $\mathrm{LiAlH}_{4}$

1,2-diaryl-2-propen-1-ols (6) from non-hydroxylated isoflavones $\mathrm{LiBH}_{4}$ or $\mathrm{LiAlH}_{4}$

\section{Conclusion}

Dietary isoflavonoids in vegetables, beans, peas and other legumes are possible cancer preventing agents, particularly in hormone based cancers such as breast and prostate cancer. [57-59] Epidemiological studies have shown that they decrease the risk of colon cancer, osteoporosis, and coronary heart disease. [1-3] Significantly, health claims of soy foods, rich in isoflavonoids, have recently received FDA authorization [60].

The dietary isoflavonoids are mainly metabolized in man via reductive pathways, leading to the reduced structural types discussed above (Figure 3). These compounds are often more estrogenic than the starting isoflavones. Research interest in many fields including medicine, nutrition and biosynthesis and metabolism thus converge on the reduced isoflavonoids. The work described in this paper shows that most structural types of reduced isoflavonoids are now reliably available in satisfactory or good yields by hydride reductions. Although not discussed here, it is clear that $\mathrm{D}$ atoms may be introduced in the same way which is very useful in the quantitation of the naturally occurring compounds by GC-MS selected ion monitoring techniques [61].

\section{Supporting Information}

\section{Supporting Information File 1}

Experimental details and characterisation data.

[http://www.beilstein-journals.org/bjoc/content/ supplementary/1860-5397-2-16-S1.doc]

\section{Acknowledgments}

This work was partially funded within the Finnish Academy project no 178253. Funding to AKS and THJ from the Foundation of Emil Aaltonen and from the Jenny and Antti Wihuri Foundation to KW are gratefully acknowledged. We thank Dr Jorma Matikainen for running the mass spectra and Ms. Jenni Maria Petäjistö for the skilful laboratory assistance. 


\section{References}

1. Cornwell, T.; Cohick, W.; Raskin, I. Phytochemistry 2004, 65, 995-1016. doi:10.1016/j.phytochem.2004.03.005

2. Cos, P.; De Bruyne, T.; Apers, S.; Van den Berghe, D.; Pieters, L.; Vlietinck, A. J. Planta Med. 2003, 69, 589-599. doi:10.1055/s-200341122

3. Duncan, A. M.; Phipps, W. R.; Kurzer, M. S. Best Pract. Res. Clin. Endocrinol. Metab. 2003, 17, 253-271. doi:10.1016/S1521-690X(02) 00103-3

4. Bezuidenhoudt, B. C. B.; Brandt, E. V.; Roux, D. G. J. Chem. Soc., Perkin Trans. 1 1981, 263-269. doi:10.1039/p19810000263

5. Jain, A. C.; Mehta, A. J. Chem. Soc., Perkin Trans. 1 1986, 215-220. doi:10.1039/p19860000215

6. Shih, T. L.; Wyvratt, M. J.; Mrozik, H. J. Org. Chem. 1987, 52, 2029-2033. doi:10.1021/jo00386a024

7. Liepa, A. J. Aust. J. Chem. 1984, 37, 2545-2558.

8. Gopal, D.; Rajagopalan, K. Indian J. Chem. 1987, 26B, 401.

9. Szabó, V.; Antal, E. Tetrahedron Lett. 1973, 19, 1659-1662. doi:10.1016/S0040-4039(01)96021-6

10. Szabó, V.; Antal, E. Acta Chim. Acad. Sci. Hung. 1976, 90, 381-393.

11. Jensen, N. P.; Brown, R. D.; Schmitt, S. M.; Windholz, T. B.; Patchett, A. A. J. Org. Chem. 1972, 37, 1639-1647. doi:10.1021/jo00975a040

12. Gannon, W. F.; House, H. O. Org. Synth. 1960, 40, 14-15.

13. Danishefsky, S.; Kerwin, J. F.; Kobayashi, S. J. Am. Chem. Soc. 1982, 104, 358-360. doi:10.1021/ja00365a095

14. Kende, A. S.; Benechie, M.; Curran, D. P.; Fludzinski, P.; Swenson, W.; Clardy, J. Tetrahedron Lett. 1979, 20, 4513-4516. doi:10.1016/S00404039(01)86636-3

15. Denmark, S. E.; Habermas, K. L.; Hite, G. A. Helv. Chim. Acta 1988, 71, 168-194. doi:10.1002/hlca.19880710120

16. Süsse, M.; Johne, S.; Hesse, M. Helv. Chim. Acta 1992, 75, 457-470. doi:10.1002/hlca.19920750205

17. Adlercreutz, H.; Musey, P. I.; Fotsis, T.; Bannwart, C.; Wähälä, K.; Mäkelä, T.; Brunow, G.; Hase, T. Clin. Chim. Acta 1986, 158, 147-154. doi:10.1016/0009-8981(86)90230-5

18. Luk, K.-C.; Stern, L.; Weigele, M. J. Nat. Prod. 1983, 46, 852-861. doi:10.1021/np50030a005

19. Antus, S.; Gottsegen, Á.; Kolonits, P.; Nógrádi, M. Liebigs Ann. Chem. 1986, 2179-2181.

20. Wähälä, K.; Valo, T.; Brunow, G.; Hase, T. Finn. Chem. Lett. 1989, 16, 79-83.

21. Antus, S.; Gottsegen, Á.; Nógrádi, M. Synthesis 1981, 574-576. doi:10.1055/s-1981-29535

22. Antus, S.; Gottsegen, Á.; Kolonits, P.; Nagy, Z.; Nógrádi, M.; Vermes, B. J. Chem. Soc., Perkin Trans. 1 1982, 1389-1394. doi:10.1039/ p19820001389

23. Májor, Á.; Nógrádi, M.; Vermes, B.; Kajtár-Peredy, M. Liebigs Ann. Chem. 1988, 555-558.

24. Jain, A. C.; Kumar, A.; Sharma, N. K. Indian J. Chem. 1991, 30B, 290-291.

25. Yamaguchi, S.; Ito, S.; Nakamura, A.; Inoue, N. Bull. Chem. Soc. Jpn. 1965, 38, 2187-2189. doi:10.1246/bcsj.38.2187

26. Anjaneylu, A. S. R.; Sri Krishna, C.; Ramachandra Row, L. Tetrahedron 1965, 21, 2677-2681. doi:10.1016/S0040-4020(01)939237

27. Badran, M. M.; El-Saba, H. M. Egypt. J. Pharm. Sci. 1991, 32, 149-155

28. Thakar, G. P.; Janaki, N.; Subba Rao, B. C. Indian J. Chem. 1965, 74-77.

29. Chidiak, H.; Kirkiacharian, S. Arm. Khim. Zh. 1996, 49, 94-104.
30. Inoue, N. Bull. Chem. Soc. Jpn. 1964, 37, 601-606. doi:10.1246/ bcsj.37.601

31. Szabó, V.; Borbély, J.; Antal, E. Acta Chim. Acad. Sci. Hung. 1979, 102, $51-57$

32. Wähälä, K.; Koskimies, J. K.; Mesilaakso, M.; Salakka, A. K.; Leino, T. K.; Adlercreutz, H. J. Org. Chem. 1997, 62, 7690-7693. doi:10.1021/ jo970892u

33. Wähälä, K.; Salakka, A.; Adlercreutz, H. Proc. Soc. Exp. Biol. Med. 1998, 217, 293-299.

34. Pihlaja, K.; Tähtinen, P.; Klika, K. D.; Jokela, T.; Salakka, A.; Wähälä, K. J. Org. Chem. 2003, 68, 6864-6869. doi:10.1021/jo0301200

35. Anjaneyulu, A. S. R.; Rao, M. G.; Row, L. R.; Krishna, C. S. Tetrahedron Lett. 1966, 7, 3199-3202. doi:10.1016/S0040-4039(01) 99937-X

36. Anjaneyulu, A. S. R.; Krishna, C. S.; Row, L. R. Bull. Natl. Inst. Sci. India 1965, 118.

37. Inoue, N.; Yamaguchi, S.; Fujiwara, S. Bull. Chem. Soc. Jpn. 1964, 37, 588-600. doi:10.1246/bcsj.37.588

38. Yamaguchi, S.; Ito, S.; Suzuki, I.; Inoue, N. Bull. Chem. Soc. Jpn. 1968, 41, 2073. doi:10.1246/bcsj.41.2073

39. Gomis, M.; Kirkiacharian, B. S. Tetrahedron 1990, 46, 1849-1858. doi:10.1016/S0040-4020(01)89754-4

40. Tsukayama, M.; Kawamura, Y.; Tamaki, H.; Kubo, T.; Horie, T. Bull. Chem. Soc. Jpn. 1989, 62, 826-832. doi:10.1246/bcsj.62.826

41. Bradbury, R. B.; White, D. E. J. Chem. Soc. 1953, 871-876. doi:10.1039/jr9530000871

42. Shoukry, M. M.; Darwish, N. A.; Morsi, M. A. Gazz. Chim. Ital. 1982, 112, 289-291.

43. Salakka, A.; Wähälä, K. J. Chem. Soc., Perkin Trans. 11999 , 2601-2604. doi:10.1039/a904946k

44. Vermes, B.; Antus, S.; Gottsegen, Á.; Nógrádi, M. Liebigs Ann. Chem. 1983, 2034-2037.

45. Bulut, M. Chim. Acta Turc. 1991, 19, 17-26.

46. Grese, T. A.; Pennington, L. D. Tetrahedron Lett. 1995, 36, 8913-8916. doi:10.1016/0040-4039(95)01916-6

47. Verma, P.; Singh, S.; Dikshit, D. K.; Ray, S. Synthesis 1988, 68-70. doi:10.1055/s-1988-27468

48. Liepa, A. J. Aust. J. Chem. 1981, 34, 2647-2655.

49. Bouvier, P.; Adrieux, J.; Cunha, H.; Molho, D. Bull. Soc. Chim. Fr. 1977, 1187-1194.

50. Deschamps-Vallet, C.; llotse, J.-B.; Meyer-Dayan, M. Tetrahedron Lett. 1983, 24, 3993-3996. doi:10.1016/S0040-4039(00)88245-3

51. Dudley, K. H.; Miller, H. W.; Corley, R. C.; Wall, M. E. J. Org. Chem. 1967, 32, 2317-2321. doi:10.1021/jo01282a049

52. Diaz, P.; Gendre, F.; Stella, L.; Charpentier, B. Tetrahedron 1998, 54, 4579-4590. doi:10.1016/S0040-4020(98)00169-0

53. Baranton, F.; Fontaine, G.; Maitte, P. Bull. Soc. Chim. Fr. 1968, 4203-4208.

54. Miyase, T.; Sano, M.; Yoshino, K.; Nonaka, K. Phytochemistry 1999, 52, 311-319. doi:10.1016/S0031-9422(99)00194-6

55. Szabó, S.; Antal, E. Magy. Kem. Foly. 1976, 10, 474-477. Chem. Abstr. 1977, 86, 55118a.

56. Kelly, G. E.; Nelson, C.; Waring, M. A.; Joannou, G. E.; Reeder, A. Y. Clin. Chim. Acta 1993, 223, 9-22. doi:10.1016/0009-8981(93)90058-C

57. Pollard, M.; Wolter, W. Prostate 2000, 45, 101-105. doi:10.1002/10970045(20001001)45:2<101::AID-PROS3>3.0.CO;2-P

58. Lamartiniere, C. A. Am. J. Clin. Nutr. 2000, 71, 1705S-1707S.

59. Wiseman, H. Expert Opin. Invest. Drugs 2000, 9, 1829-1840. doi:10.1517/13543784.9.8.1829 
60. Federal register 64FR57699, U.S. Food and Drug Administration. Oct 26, 1999.

61. Adlercreutz, H.; Fotsis, T.; Lampe, J.; Wähälä, K.; Mäkelä, T.; Brunow, G.; Hase, T. Scand. J. Clin. Lab. Invest. 1993, 215, 5S-18S.

62. Gensler, W. J.; Johnson, F.; Sloan, A. D. B. J. Am. Chem. Soc. 1960, 82, 6074-6081. doi:10.1021/ja01508a026

63. Fisher, G. B.; Harrison, J.; Fuller, J. C.; Goralski, C. T.; Singaram, B. Tetrahedron Lett. 1992, 33, 4533-4536. doi:10.1016/S0040-4039(00) 61305-9

64. Olah, G. A.; Wang, Q.; Prakash, G. K. S. Synlett 1992, 647-650. doi:10.1055/s-1992-21443

65. Ibrahim, A.-R.; Abul-Hajj, Y. J. J. Nat. Prod. 1990, 53, 644-656. doi:10.1021/np50072a011

66. Osawa, K.; Yasuda, H.; Maruyama, T.; Morita, H.; Takeya, K.; Itokawa, H. Chem. Pharm. Bull. 1992, 40, 2970-2974.

\section{License and Terms}

This is an Open Access article under the terms of the Creative Commons Attribution License

(http://creativecommons.org/licenses/by/2.0), which permits unrestricted use, distribution, and reproduction in any medium, provided the original work is properly cited.

The license is subject to the Beilstein Journal of Organic Chemistry terms and conditions:

(http://www.beilstein-journals.org/bjoc)

The definitive version of this article is the electronic one which can be found at: $\underline{\text { doi:10.1186/1860-5397-2-16 }}$ 